\title{
Cosmocracy: A Hymn for the World? Reflections on Michel Serres and the Natural World
}

\author{
Mary Zournazi, University of New South Wales
}

Who thinks like the dying sea? What writer, other than Homer or Conrad, thinks like the wind? Michel Serres, Biogea (2012: 88).

Tell me the difference between soul and wind. Michel Serres, The Five Senses (2008: 172).

Michel Serres's recently translated book into English, Biogea, is a plea to the world. Serres is a lover of language, myth and the world. Biogea appears to be a composite word, invented for us: bio meaning life and gea of the earth. Between bio and gea, Serres explores poetic, mystical, philosophical and scientific accounts of how listen to the world. Who listens like the wind? What stories can make us think with it? What Mysteries? What Loves? For Serres, without this connection to the world we will not survive the onslaught of human violence and malfeasance toward it.

Serres traces stories of the natural world through his own experience as a seafarer and naval officer. His relationship to the sea is a fundamental element of the book as well as his family legacy. For Serres, the sea embraces the most primordial category and experience, for it is the water that flows, and it is the water that carries life-we are made of hard and soft things, he says. 
Interconnected by sea stories and influenced by ancient philosophies and myths, the book explores the fundamental elements of the world such as fire, air, water and earth as well as other significant phenomena. Each chapter bears the relation to these elements and the chapters are appropriately titled earth and mountains, three volcanoes, winds and atmospheric phenomena, flora and fauna, and lastly encounters, loves.

In essence, the book explores previous incarnations of 'bio-technologies,' as well as networks of confluence and communicative channels in the world, but we have yet to fully comprehend our limited vision of it. We must work against our own destructive and invasive tendencies. He writes:

\begin{abstract}
Once again, we cannot claim to be subjects in the midst of a world of objects, for our behavior resembles that of other insects, other rodents or poisonous plants. Not separated, but plunged, immersed in the Biogea, in cousin company. I want to think like that company, in it, by it, with it, for it.

Warning! We can no longer resolve ourselves to this war of every man against every man, fatal in the final analysis to the entire Biogea and consequently to us. Peace. Would a new Eden emerge if we agreed to a Natural Contract?
\end{abstract}

Which?

Drawn up in what language? (2012: 107).

We might think of Serres's writing as a kind of 'geographical writing' ${ }^{1}$ —a writing about the Earth. At the same time, we might consider his writing as 'angelology'-a writing that moves between unknown and known phenomena and perceptions. Through his writing movement and perception are reconfigured. And throughout his books, this 'method' sustains him. He states this effort in the following way:

\begin{abstract}
My effort consists of abstracting, throughout the duration of relations, the different mailmen or messengers-represented by the god Hermes or the host of angels-who serve as delivery persons for prepositions. This is the reason for my attraction to topology-the science of proximities and ongoing or interrupted transformations - and my attraction to percolation theory and to the notion of mixture. (Serres \& Latour 1995: 105)
\end{abstract}

Biogea is a very personal work just as much as it is a treatise for a different ontology of being and perception, knowledge and justice. Serres asks us to consider the natural world outside of the usual human appropriation of it. In this regard, the book continues a path signaled by his earlier works. This path is concerned with how to relate to the

\footnotetext{
${ }^{1}$ See Stephen Connors’s introduction to Michel Serres’s The Five Senses (2008).
} 
world rather than to struggle and control it. In his conversations with Bruno Latour (1995) he continues:

\begin{abstract}
It's better to paint a fluctuating picture of relations and rapports—like the percolating basin of a glacial river, unceasingly changing its bed and showing admirable network of forks, some of which free or silt up, while others open up —or like a cloud of angels that passes, or the list of prepositions, or the dance of flames.
\end{abstract}

I want to finish drawing this navigational map, this inventory—fluctuating and mobile—before I die. Once this work is done it will be clearly seen that all the rapports I traced out either followed or invented a possible road across the ensemble of movements from place to place. Note that this maritime chart, an ocean of possible routes, fluctuates and does not remain static like a map. Each route invents itself. (Serres \& Latour 1995: 105)

Throughout Biogea, Serres inverts our relation to the natural world. Calling upon images of the mother earth, he suggests that humanity can no longer be viewed as floating in the mother's amniotic fluid; rather the earth floats like a foetus itself. In this foetal state, the earth is connected to a thousand different networks, cords and bonds, all of which are essential to the earth's survival. And through these different bonds, Serres looks at the earth as the intermingling of different voices and images: a daughter, mother, lover - all of these networks and connections that joins forces with us, not against us. The world speaks, it converses with us, but we rarely hear it.

Like Biogea, his earlier books The Natural Contract (1995) and the Five Senses (2008) question our usual understandings of identity, empiricism and knowledge. Recounting his experience of an earthquake in The Natural Contract, Serres eloquently observes the intermingling of life and force to challenge us:

\footnotetext{
Who am I? A tremor of nothingness, living in a permanent earthquake. Yet for a moment of profound happiness, the spasmodic Earth comes to unite herself with my shaky body. Who am I, now, for several seconds? Earth herself. Both communing, in love she and I, doubly in distress, throbbing together, joined in a single aura.
}

I saw her formerly with my eyes and my understanding; at last through my belly and my feet, through my sex I am her. Can I say that I know her?

Would I acknowledge her as my mother, my daughter, and my lover together? Should I let her sign? (1995: 124)

Altogether, in Biogea he looks at the symbiotic relations of earth and bodies, and their intermingling through different phenomena and myth. As Serres recasts the mother in Biogea, he reminds us of the fluidity of the 'soft.' The soft remains. It endures. His 
fundamental thesis is: 'the hard does not last, only the soft lasts' (2012: 192). He gives a horrifying image of the graveyards of the 'hard.' Hard things wear away, but the soft elements continue. He asks: who has seen the cemeteries of the soft, 'for breaths and sounds, music, letters and codes, signs and meaning?' The hard is what remains and is polluting:

I invite you to visit the places where the history of technology is read best: ship graveyards, railroad yards, downgraded cranes, whose masses border the typewriters and computers of the first and even the more recent generations... Rusted ironmongery fit for making scrap metal merchants rich.

Let's pass from these iron scraps, hard as dirt, to streaming liquids, water. Let's repeat that time flows ... (2012: 190-91)

I can attest to the graveyards of the hard and their effects. Only yesterday, I saw a pigeon dazed and confused in the middle of a busy road. Obviously it was injured and in a state of shock. I was concerned for the bird, but could see no way of helping it. I could predict its fate, which was disturbing. Amid the constant movement of large trucks and cars, drivers could not see the bird's shocked status even though I could see it; briefly a car stopped, its driver aware of the bird, but the others behind it had no such vision. Within an instant the bird was run over. Soft flesh splattered on the cold hard asphalt; one of its wings fluttering in the wind. The bird may have been run over twice: in the first instance shocked but not dead yet, in the second instance, assuredly so.

The pigeon had no real chance of survival. I lamented the brutal technology of speed and the indifference of cars and trucks at that moment. This might seem like an inconsequential encounter. Who cares about the pigeon? But this question of care must be asked of our relations to the world. Every moment. Every encounter. In the bigger picture, the bulldozers of technology destroy the earth through the thoughtlessness of speed and indifference. Who thinks like this bird?

What of the soft and the fluid?

For Serres, we are only interested in our own stories; we never hear the plentitude of the soft. The sea is dying, is polluted. We are unable to see the languages or codes that are not our own. We only ever acknowledge language and convention; and when language boils down to convention and contracts without soul or connection, we create stories 
about places and things, rather than with them. We do not see what we encounter in this world; nor are we able to comprehend it.

In this violence, we lose the path of relation. We lose the ability to connect to the networks and threads that exist and surround us. We lose the potential for rebirth, and ultimately the link between the past, present and the future:

[ ... ] we're only interested in ourselves and our properties. Never in others. I'm not only talking about other ourselves, those who, resonating with languages said to be foreign, nevertheless buzz with human languages. But other others: belling or howling living things and resonating things. Yet we're beginning to decipher the codes of living things-true living languages, authentically foreign — and the inert things of the Earth, both of which, like us, receive, transmit, store and process information. Formerly philosophers understood that everything conspires or consents. We now know that the Biogea converses. Scientific or imagined, my brief short stories have tried to make the foreignness, no doubt still unfelt, of these languages heard by building a first megaphone for Gea: seas, rivers, lands, glaciers, volcanoes, winds; then for Bio: rats, wolves and jackalsfauna, apple trees, wisteria, oaks and lindens_-flora; lastly by connecting these megaphones to our own encounters and cries. Swirling, the ascent goes from the hell of noise to the smaller and smaller paradise of the said.

At the summit: the non-written or the non-said. (2012: 196-97)

Serres considers the need for an intuitive global philosophy that invents and creates, rather defends and destroys others. He argues that we fight against the unsaid of the world, in our fear and through our knowledge. In the Hobbesian account of nature as the 'war of all against all,' the basis of sovereignty and law that are aimed to protect us from nature but in doing so creates a fundamental schism in our living relations. Writing against this Hobbesian worldview and its legacies, Serres demands a 'natural contract.'

In the first chapter of The Natural Contract, he gives a striking image of this dialectical world. Using Goya's painting Men Fight with Sticks: where two duelists are fighting in the mud, Serres demonstrates how the duelists are sinking in the quicksand that surrounds them. The more aggressive their strikes, the faster they sink. He writes that these combatants are representative of a humanity where wars are fought and lost, and blood is spilled over occupied territories. But this ground can never be owned by any man; even though humans violently appropriate everything in their own image and name. In his account of the Goya painting, 'The earth will swallow up the fighters before they and the gamblers have had a chance to settle accounts' (1995: 1). 
According to Serres, this societal contract of a 'war of all against all' leads us nowhere and is murderous to the living world. Thus, in Biogea, he explicitly states that humanity as a collective under this worldview must be put on trial:

How does it happen that society accuses and punishes an individual who, perchance, has killed, while no society, no individual accuses society which, for its part, always kills? For, killer, the collective collects itself by killing. What authority one day called together will accuse every group of murder? The abolition of the death penalty takes the first step in that direction. You, society, you no longer have the right to kill. (2012: 21)

How do we understand this profound disjunction between the world and ourselves? The world has awesome and terrifying qualities that require respect; the earth speaks even though we render it conceptually and contractually silent. Serres wants a different understanding of the term 'contract.' Etymologically speaking, Serres argues that the word contract includes the notion to 'com-prehend.' In this comprehension, we come together—we are 'intercorded' as he suggests—or put differently we exist within a whole natural system that is connected but its language has yet to be understood. Therefore, contracts must not necessarily presuppose language: a 'set of cords can be enough,' he writes. Just like his foetal earth that requires its bonds and cords to evolve and to endure, the dynamics of the natural world, its energies, fluctuations and turbulences are part of the unfolding contract. It is necessary that we com-prehend it:

\begin{abstract}
We are apprehended together and we apprehend one another, intercorded, even when mute; better yet, the contract blends our constraints and our freedoms. The information that we each receive through our tip of the cord informs us, in the end, not only about everyone else who's encorded, but about the overall state of the whole system to which we belong. The bond runs from place to place, but also, at every point, expresses the totality of sites. It goes, for sure, from the local to the local, but above all from the local to the global and from the global to the local. The contract thus affects us as individuals by making us immediate participants in our entire community. It blends solitaries into communities. (1995: 107)
\end{abstract}

How we navigate these 'cords' and bonds shape the force and power that can enslave or liberate us. Serres continues:

When flexible, it embraces topology, only to describe geometrical forms once it stiffens. By means of brief little pulls, it conveys information, at low energy levels, whereas, when continuously pulled taut, it transmits force or power, high energy levels. At its constraining limits it imprisons, but it leaves elbowroom prior to this maximum. In the cord, we find the sciences of space and the genesis of their objects, a well as the technologies of force or energy; who can be surprised that the cord also binds together rigorous knowledge and law? (1995: 108) 
Serres argues that the interrelatedness of all things has been lost through the specialisation of our knowledges; and in this specialisation, we create conceptual hatreds and hardness as well as the fragmentation of time and space:

\begin{abstract}
Our analytical hate bursts into these little puzzle pieces, into these texts armored with compelling, aggressive, defensive citations. In fragmented lives, we think a world burst into technologies, sciences, separated languages. Our meaning lies in scattered limbs. By dint of quartering the subjective, the cognitive, the objective and the collective, how can we say the right word and live a happy life? The analysis that unties these four components comes from the hate that divides. What love will reunite them? That's the project of a thought, the program of a language, the hope of life. (2012: 75)
\end{abstract}

Serres is inspired by various myths and philosophies that bring unity and hope in even in the midst of death. In particular, he cites the ancient Greek philosopher Empedocles who, as the legend would have it, jumped to his death in the volcanic crater of Mount Etna. For Serres, Empedocles was exemplary-he was a serious scholar of science, poetry and phenomena. His approach to the world unites us and prepares a path of rupture, and invention. For Empedocles, what unites is love, what separates us is hate (but we might say what truly separates us is indifference). For Serres, Empedocles death marked his profound belief in the world. He believed in the vital elements of earth, air, water, fire and the constant movement and cycle of these elements; life as the continual force of movement and energy:

When Empedocles wrote about love and hate, he meant at once physics and society, the living body and the surrounding world, myth and knowledge, music and exactitude, moving emotion and untrembling rigor, my soft girlfriend and the implacable hardness of things. I want to speak like him, at the global dimension of the world in which we live and think like guests. (2012: 75)

How to think and speak like Empedocles? For Serres, this is a serious question; it is a question of time and how we view our connection to the earth. Even more so, it is how we understand the enduring rhythms and qualities of the earth as well as the love that unites our time and place of belonging to it. He writes that as humans we live in temporary locations, for no one really owns the earth. In some ways, this view of temporary inhabitation as well as the enduring qualities in which pass onto others is the paradox of our humanity. But it is with a different sense of time that we must acknowledge the transience of life as well as all that endures beyond our limited visions of it. He puts it this way:

We will always depart and leave the Earth to others than us, whose habitat will continually pass to others and to others, indefinitely. We live in a rented location; not only on the Earth, in Gea, but also in Bio, I mean in our bodies, which carry within them what, indefinitely, makes the opening 
for the relay of the species. The body is not only for itself, it carries in itself for those that follow, as well. I live my body in transitive rented location.

The new habitation. For if we, renters, have to assume the responsibility of maintaining a merely temporary habitat, quite common to everyone across space and time, in order to pass it on to successor as habitable and beautiful as we received it from our predecessors, without soiling it with blood or other stains so as to appropriate it for ourselves, we must live, in some way, at the same time there and outside the there, between here and elsewhere, in the opening between two worlds, in the place of our loves and our works, certainly, but at the same time apart, in the symbolic and the concrete, the second receiving its meaning from the first. Failing this temporary rented locations, thus open and gapped, a third death would arise on the horizon: the eradication of our species, the disappearance of the human race. That is a limit-hell whose current pregnance induces us to frequent an elsewhere. No doubt we have our feet on the Earth, hard, and our heads in the soft. (2012: 49-50)

The thrust of Biogea is that we have to change our perceptions of the natural world. As in his previous book Malfeasance (2011), as well as in The Natural Contract, he writes that the natural contract engages 'peace with us' and peace for the world. And in this peace-making it is our perception that must become 'res nullius'-the 'object of noone.' That is, no one can make a claim on behalf of the earth, our perceptions must be the object of no-thing. He writes: 'the new contract becomes a rental agreement. Once we have become mere renters we will be able to contemplate peace-peace among humans because peace with the world. May this cosmocracy come soon' (2011: 72).

I take this cosmocracy seriously. Serres's cosmocracy is a hymn for the world that relies on a different speech and invention than usual philosophical and scientific languages. In recent philosophical and cultural debates, we may be more familiar with the 'cosmopolitics' of Isabelle Stengers and Bruno Latour's considerations of it. But Serres tacitly informs Latour and Stengers view of the cosmos and their philosophies and sociologies of science, ${ }^{2}$ and he asks us to bear witness to the world and the unity of love. He invites us to consider the interrelatedness of all things through the intermingling of different systems of knowing and feeling, and myth and poetry.

Thinking with Serres is a task of suspending our preconceived ideas about science and philosophy. For me, his work offers a kind of relief. It allows me to think a kind of rebirth of action, thought, and knowledge. But this requires patience and love. Love in

\footnotetext{
2 See Bruno Latour's conversations with Michel Serres, Conversations on Science, Culture and Time (1995a), and Isabelle Stengers, Cosmopolitics 1 (2010) and Cosmopolitics 11 (2011).
} 
its uniting sense, not as a romantic or a filial state, but a deeper sense of unity and connection. Calling forth different legends and myths, Serres reminds us of the cycles of birth, life and death as well as the energy and connection we have with this planet.

To end: is Serres a visionary? Maybe. For me, his book is a love letter; a hymn for the world.

\section{Reference List}

Serres. M. 1995, The Natural Contract, trans. E. MacArthur and W. Paulson. University of Michigan Press, Ann Arbor. 2008, The Five Senses: A Philosophy of Mingled Bodies, trans. M. Sankey \& P.r Cowley. Continuum, London. 2011, Malfeasance: Appropriation Through Pollution, trans. A.-M. Feenberg-Dibon. Stanford University Press, Stanford. 2012, Biogea, trans. R. Burks. Univocal, Minneapolis.

Serres, M. with Latour, B. 1995. Conversations on Science, Culture and Time, trans. R. Lapidus. University of Michigan Press, Ann Arbor.

Stengers, I. 2010, Cosmopolitics 1, trans. R. Bononno. University of Minnesota Press, Minneapolis. 2011, Cosmopolitics 2, trans. R. Bononno. University of Minnesota Press, Minneapolois.

Zournazi, M. with Serres, M. 2003, ‘The Art of Living,' in Hope: New Philosophies for Change. Routledge, New York, pp. 192-209. 